\section{AB0125 RAPID AND COMPLETE REMISSION IN TREATMENT RESISTANT ANKYLOSING SPONDYLITIS WITH ETANERCEPT - A BETTER DRUG FOR REFRACTORY AS THAN FOR REFRACTORY RA?}

HR Barthel. Koenigstein, Germany

10.1136/annrheumdis-2001.334

Background Two treatment-resistant, HLA-B27 positive patients with ankylosing spondylitis (AS-pat.1\&2) are described in whom etanercept led to a rapid profound improvement in symptoms as well as normalisation of CRP.

Objectives

Methods AS-pat.1 is a 37 y.o. male with highly active AS with generalised stiffness and pain. Subcutaneous (s.c.) weekly MTX over one year in addition to the prior regimen of indomethacin $150 \mathrm{mg} / \mathrm{d}$ led to only moderate improvement in symptoms and reduction of CRP from $8 \mathrm{mg} / \mathrm{dl}$ to $4 \mathrm{mg} / \mathrm{dl}$. A trial of $\mathrm{I}$. V. pamidronate failed. Etanercept $25 \mathrm{mg}$ s.c. twice/wk was added to MTX. He reported an immediate dramatic improvement of symptoms and stopped indomethacin the day after the first injection. CRP normalised. MTX was stopped after 1 month. He describes a "new life" and that he now plays badminton with his children which he was unable to do before.

AS-pat.2 is a 66 y.o. male with longstanding AS and a history of recurrent iritis. He suffered from morning stiffness and from repeated flarings of varying peripheral joints despite corticosteroid joint injections, indomethacin up to $150 \mathrm{mg} / \mathrm{d}$ and a $21 / 2$ months trial of MTX $15 \mathrm{mg}$ weekly. Etanercept $25 \mathrm{mg}$ s.c. twice weekly led to rapid and dramatic improvement of pain and stiffness within 2 days, such that the patient did not continue MTX. CRP of $3 \mathrm{mg} / \mathrm{dl}$ normalised. No new flare of arthritis or iritis has occurred.

Results Both AS-pat. results (follow up of 8 months) appear particularly remarkable since none of the 9 RA pat. (disease duration more than 4 years, more than 3 failed DMARDs) treated with etanercept-DMARD combination in the same practice (community based, single practitioner rheumatology) in a one year period (9/99-8/2000) had a similar response. Only 4 stayed on etanercept, 3 withdrew due to lack of efficacy, 2 because of side effects.

Conclusion The herein described profound improvement of so far treatment resistant AS with etanercept and its superior efficacy for AS compared to RA warrants further confirmation. Etanercept's only moderate benefit for RA in this setting might be explained by a selection of aggressive cases not having responded to prior DMARD combination therapy.

\section{AB0126 ASSESSMENT OF SULPHASALAZINE (SS) AND METHOTREXATE (MT) EFFICACY IN TREATMENT OF ANKYLOSING SPONDYLITIS (AS).(PRELIMINARY DATA)}

SN Tchepeleva, GV Loukina, YA Sigidin. Department of Clinical Pharmacology, Institute of Rheumatology, Moscow, Russia

\subsection{6/annrheumdis-2001.335}

\section{Background}

Objectives To assess the efficacy of methotrexate and sulphasalazine in patients with active AS.

Methods 30 patients with AS satisfying the New York criteria for AS were randomly divided into two groups. One group (21 patients) received $1.5-2 \mathrm{~g} / \mathrm{d}$ SS for 6 months and the other (9 patients) - methotrexate $7.5-10 \mathrm{mg} /$ week. 25 clinical and laboratory criteria were assessed. Positive changes (over 20\% from baseline) in 20 and more variables were considered as excellent effect; 14-19, good; 6-13, moderate; 1-5, no response.

Results 21 patients completed the study (17 on SS and 4 on MT). In SS group there were 2 patients with excellent effect, 6 with good effect, 7 with moderate one and only 2 had no response. 3 patients treated with methotrexate had moderate effect and 1 patient had good one. 5 patients dropped out of the trial due to adverse reactions: 3 in MT group (liver enzymes elevations, low back pain, myalgia/ossalgia) and 2 in SS group (allergic rash, taste disorder). We observed several transient side effects. 2 patients from SS group complained of dizziness, that resolved spontaneously. One of them had anaemia, for which he experienced benefit with folic acid. One patient had concentration disorder.

Conclusion These data suggest that SS is an effective treatment for AS and it is necessary to continue this comparative study.

\section{AB0127 THYROID HORMONES IN PATIENTS WITH ANKYLOSING SPONDILITIS OR PSORIATIC ARTHRITIS}

${ }^{1}$ AT Kotulska, ${ }^{1}$ EJ Kucharz, ${ }^{1} \mathrm{~J}$ Go?dzik, ${ }^{2} \mathrm{D}$ Kapo3${ }^{3} \mathrm{ka},{ }^{2} \mathrm{~W}$ Liwoch-Morzo3. ${ }^{1}$ Internal Medicine and Rheumatology, Medical University of Silesia, Katowice; ${ }^{2}$ Division Rheumatology, Silesian Hospital of Rheumatology, Ustroñ, Poland

\subsection{6/annrheumdis-2001.336}

Background Ankylosing spondylitis (AS) and psoriatic arthritis (PA) are diseases related to a group of arthritides known as seronegative spondyloarthropaties. Exraaarticular manifestations of SA or PS are a common feature. Thyroid gland involvement have been reported in almost all systemic rheumatic disorders.

Objectives The present study was designed to evaluate serum thyroid hormones in patients with SA or PA.

Methods Fourty patients $(11 \mathrm{~F}, 29 \mathrm{M})$ aged $52.2+1.9$ yrs with AS and 13 patients $(4 \mathrm{~F}, 9 \mathrm{M})$ aged $46.4+11.2$ yrs with $\mathrm{PA}$ as well as 10 healthy subjects $(3 \mathrm{~F}, 7 \mathrm{M})$ aged $51.2+2.6$ yrs were investigated.

Serum thyroid hormones and thyrotropin levels were measured in all investigated individuals.

Results A decrease in total triiodothyronine and total and free thyroxine was found in the AS patients. No changes in thyroid hormone levels were found in the PS patients.

There was no correlation between the hormone levels, age, ESR and duration of symptoms, except negative correlation between free triiodothyronine and ESR in the controls $(r=-$ 0.5977), ESR and total triiodothyronine $(r=-0.2160)$ and ESR and total thyroxine $(r=0.2321)$ in the AS patients.

Conclusion From clinical point of view, thyroid involvement in AS or PA seems to be less important than in patients with other systemic rheumatic diseases.

\section{AB0128 USEFULNESS OF MRI FOR THE DIAGNOSIS OF INFLAMMATORY SACROILIITIS}

${ }^{1} \mathrm{R}$ Ghozlan, ${ }^{1} \mathrm{M}$ Dupuis, ${ }^{2} \mathrm{~J}$ Mani, ${ }^{2} \mathrm{~S}$ Marciano. 'Rheumatology Service; ${ }^{2} \mathrm{MRI}$ Department, Hopital Europeen de Paris La Roseraie, Aubervilliers, France

10.1136/annrheumdis-2001.337

Background The diagnosis of sacroiliitis is usually performed on $\mathrm{X}$-rays but frequently this method of imaging can be normal and 